\title{
Banking Services Marketing via Social Media Platforms and Its Impact on Consumer Behavior During COVID-19 Pandemic in Jordanian Banks: Mediating Role of Innovation Marketing
}

\author{
Naseem Abu Roman ${ }^{1}$ \\ ${ }^{1}$ Banking \& Financial Sciences Department, Faculty of Business \& Finance, The World Islamic Sciences \& \\ Education University (W.I.S.E), Amman, Jordan \\ Correspondence: Dr. Naseem Abu Roman, Banking \& Financial Sciences Department, Faculty of Business \& \\ Finance, The World Islamic Sciences \& Education University (W.I.S.E), Amman, Jordan.
}

Received: March30, 2021

doi:10.5430/ijfr.v12n4p239
Accepted: May 5, 2021

Online Published: May 21, 2021

URL: https://doi.org/10.5430/ijfr.v12n4p239

\begin{abstract}
This study aimed to know the impact of marketing via social media platforms (MSMP) during the Covid-19 pandemic on consumer behavior (CB) in Jordanian banks. In addition to knowing the role of innovation marketing (IM) in improving the ability of the impact of MSMP on CB during the Covid-19 pandemic. The study population consisted of all Jordanian banks. The process of distributing and retrieving the questionnaires was carried out electronically due to the COVID-19 pandemic and the ban imposed in Jordan. The study found an impact of MSMP during the COVID-19 pandemic in IM, Also, MSMP helps to innovate in the way social interactions occur between individuals and banks. The study also found an impact of MSMP on CB during the COVID-19 pandemic. The study also showed that there is an impact of IM in improving the impact of MSMP on CB. The study recommends the need to pay attention to MSMP as it adds very important elements to traditional marketing during the COVID-19 pandemic.
\end{abstract}

Keywords: consumer behavior, COVID-19 pandemic, innovation marketing, marketing, social media platforms

\section{Study Background}

\subsection{Introduction}

The world today is experiencing a technological revolution, brought about by the emergence of the Internet, and the services that this network provided to individuals and business organizations (Zraqat, 2020), including e-marketing service and MSMP, as this type of marketing, has enhanced a critical part of the contemporary marketing strategy. This led to the banks adopting a new way of understanding $C B$, as it furnished him an occasion for dialogue between banks and customers, as straight dialogue between these two parties became viable, which led to the advancement of connections between them, so the bank will offer a suitable product and the customer will pay for the banking product or service after knowing his behavior patterns, transcending the limits of time and place, and the customer accesses banking products and services easily. Most buyers currently own and use a kind of digital tools such as computers, mobile devices, and social media such as Facebook, Instagram, Twitter, WhatsApp, and YouTube, which provide to the excellent progress of digital marketing (DM) activities (Akter and Sultana, 2020).

The social media platforms (SMP) that have spread and increased in their plenty of users on the web represent a modern revolution in human ideas, as they allow real-time and interactive dialogue between people equated to the Internet via classified groups with common interests and without an intermediary (Alotaibi et al., 2021). As was the case before it in the traditional media or even in the websites and electronic newspapers which have also become traditional by the standard of these new networks. The effect of using social media networks is no longer limited to exchanging information between individuals, but rather to electronic marketing activities, where many banks publish their information and present their offers for their products and services through social networks. Social networking sites are no longer just for dating. Rather, it has become a powerful and very effective marketing tool for business organizations including banks, being low-cost, and ensuring easy communication with them inside and outside the workplace, in addition to the ease of joining and subscribing to them. Where it has the ability to design and develop, 
and to categorize subscribers according to age, gender, interests, hobbies, and ease of linking business with customers, the experience of marketing via networks increases communication with consumers.

The rapidly changing developments surrounding the COVID-19 epidemic have created an ideal environment for enhancing the ability of social media to provide instant mass communications (Theep, 2021). The COVID-19 pandemic has resulted in individuals staying indoors and consuming more time on the Internet (Maulana, 2020). Which led to the transfer of the potential market towards digital. The COVID-19 pandemic has transformed all aspects of living the way we used to know, think and live (Fernando et al., 2021). Lockdown and fear of spreading the infection have altered consumers' attitudes, behaviors, and spending habits (Algharabat et al., 2020). Consumers have now turned to obtain products and services on demand, as physical store closures have forced consumers to change their inherent shopping habits (Akter and Sultana, 2020). People have created online accounts and SMP for a new customer journey. Brands are also becoming increasingly dependent on the direct-to-consumer (D2C) business model via digital and mobile channels (Zwanka \& Buff, 2021). This transformation will help change both the methodology of marketing innovation and CB. Which led to the marketers and consumers trying to adapt to this new situation. In order to face these conditions, companies including banks had to innovate in the field of marketing (Dumitriu \& Popescu, 2020). These challenges have forced banks to search for ways to differentiate the products and services they offer, especially with regard to products and services related to information technology and the digital revolution, and this requires the innovative and entrepreneurial capabilities of these banks in all aspects of their operations. On the other hand, developing innovative products is no longer sufficient in the time of the COVID-19 pandemic if it has not coincided with innovative and pioneering marketing policies. Hence, this study came to identify the role of the mediating role of IM in the impact of MSMP during the COVID-19 pandemic on CB in the Jordanian banking sector.

\subsection{Study Problem}

The COVID-19 pandemic has created unprecedented economic and health concerns (Harahsheh et al., 2021), which have prompted banks to change their perceptions of various aspects of the business. As banks began to think about how to maintain and expand their brand and customer base (Arafat et al., 2020). Most of the real-life events such as exhibitions, conferences, workshops, and trade fairs scheduled to take place during the COVID-19 pandemic period have been canceled, which has prompted marketers to seek other places to spend their marketing money (Brizi \& Biraglia, 2021). The banks changed their marketing strategies and introduced innovative marketing practices to face the new situation. Whereas, with the change of $\mathrm{CB}$, its shift to the digital world, and with the increasing number of consumers using SMP to search for products that they can buy from their homes, the need for banks to market innovation and invest in more marketing strategies through SMP has emerged.

Jordan was not far from the global impacts associated with the COVID-19 pandemic, as Jordan testified a dominant shift in CB after the emergence of the COVID-19 pandemic, prompting quarantine measures and the consequent social distancing measures, and closing shops to limit the spread of the pandemic since March 2020, to force people to stay at homes and shop via SMA, which are no longer a space for communication and chatting only, but rather a space for shopping, and a substitute for regular shopping during the quarantine period, thus becoming platforms for displaying various banking products and services, and a space for interaction between producers. Hence the problem of the study arises in answering the following questions:

1. Is there an impact of MSMP during the COVID-19 pandemic on CB in Jordanian banks?

2. Is there an impact of IM in improving the impact of MSMP during the COVID-19 pandemic on CB in Jordanian banks?

\subsection{Study Objectives}

1. Identify the level of MSMP during the COVID-19 pandemic among Jordanian banks.

2. Identify the level of IM during the COVID-19 pandemic among Jordanian banks.

3. Identify the effect of MSMP during the COVID-19 pandemic on CB in Jordanian banks.

4. Identify the impact of MSMP during the COVID-19 pandemic on CB in Jordanian banks through IM.

\section{Literature Review and Hypotheses Development}

\subsection{Consumer Behavior (CB)}

CB emerged in the 1940's and 1950's as a distinct subsystem in the field of marketing. CB is an interdisciplinary social science blending element from psychology, sociology, social anthropology, ethnography, marketing, and 
economics, especially behavioral economics (Fernando et al., 2021). It studies how emotions, attitudes, and preferences affect buying behavior. Individual consumer characteristics such as demographics, personal lifestyles, and behavioral variables such as usage rates, the suitability of use, loyalty, and brand advocacy are examined, and the willingness to provide referrals in an attempt to understand people's desires and consumption in official studies of CB. Walters, (1974) Defines CB as a subset of human behavior, which includes how individual deals with his environment, and sees it as including every thought, feeling, or action by people that affects the process by which individuals decide whether what, when and from where how do they buy goods and services. Belch \& Belch (2004) also provides a link between human behavior and $\mathrm{CB}$, by noting that $\mathrm{CB}$ has been defined as the study of human behavior in the role of the consumer. Mowen (1987) provides a different definition by explaining CB as the study of purchasing units and exchanges involved in the acquisition and consumption of goods, services, experiences and ideas, and their disposal, and the researcher notes that this definition focuses on purchasing units in an attempt to include not only the individual but also, groups that buy products or services.

The study of CB has also been defined as the study of individuals, groups, or organizations, and all activities related to the purchase, use, and disposal of goods and services, including consumer emotional, mental, and behavioral responses that precede or follow these activities. CB includes all activities that individuals undertake in order to obtain goods and services, and their use, including activities that precede the purchase decision and affect the buying process. We note from this definition that studying CB requires knowledge of the factors and influences that affect consumer buying behavior (Jermsittiparsert \& Chankoson, 2019).

According to the Veblenian social model, people act according to the characteristics of the group to which they belong, as people aim to align their behavior with group preferences, as people's desires and needs follow the groups with which they interact, although there are critics who argue that this theory Exaggerated, however, it influences CB, as people tend to prefer what they feel desirable in their social circles (Murphy \& Dweck, 2016).

\subsection{Consumer Behavior in a Time of the COVID-19 Pandemic}

According to Dammeyer (2020), Market Psychology refers to: "The study of individuals, groups, or organizations, and the processes they use to select, secure, use and dispose of products, services, experiences, or ideas to meet the needs and impacts that these processes have on the consumer and society". So, understanding CB during the COVID-19 pandemic in banks is worthwhile, because market psychology directly affects how consumers behave during a pandemic. The pandemic has led to significant changes in CB around the world. As consumers become more rational, interested in SMP, and enjoying skills and multitasking capabilities in the virtual world, during the COVID-19 pandemic, consumers individually evaluate when making purchasing decisions and making use of banking services by searching the Internet by searching the Internet (Clemens et al., 2020). Coibion et al. (2020) showed that $46 \%$ of consumers in Peru reduced their expenditures related to luxuries and luxury products while increasing expenditures on emergency products and household supplies during the COVID-19 pandemic. And that is done through online shopping in all stages of the behavior of the purchase decision. Zwanka and Buff (2021) reviewed the potential impact of the COVID-19 pandemic on global CB and other marketing activities and stated that the COVID-19 pandemic will lead to shifts in CB around the world, which will necessitate marketers to find new innovations marketing strategies to match the patterns new CB. Akter and Sultana (2020) show that innovation in digital marketing communications has influenced $\mathrm{CB}$ at all stages of purchasing decisions and that customers have had decisive sentiments about SMP during this COVID-19 pandemic.

\subsection{Marketing via Social Media Platforms (MSMP)}

Due to the proliferation of affordable smartphones, and easy path to cheap data, the amount of people with internet path across Jordan has dramatically. This situation called on banks to communicate with their target customers (Theep, 2021). They can simply do this via SMP. Thus, cyberspace has become vital, because people will do research online before purchasing a product or receive banking services. Digital devices enable consumers to compare costs and find the most desirable value. Dahiya (2013) indicated that more than $80 \%$ of individuals depend on the information that is provided through the Internet for their purchasing decisions, which indicates that marketing activities via SMP have a great role in all CB.

Electronic marketing is described as the marketer's promotion via digital distribution channels such as smart phones (Smith, 2012). Chen \& Lin (2019) defined electronic marketing as the marketing activity carried out by organizations via various media such as blogs, websites, email, word of mouth, and various SMP. MSMP is also defined as the marketing activity that uses SMP as a marketing channel (Kujur \& Singh, 2017). MSMP aims to help companies including banks increase their market share and purchase plans for their customers (Manzoor et al., 2020). 
Historically and to this day, the prevailing cross-platform business model has included generating income for users by providing promotion services to those wishing to access markets with digital content and marketing communications (Appel et al., 2020). Several studies have indicated the usefulness of social media in marketing. For example, Stephen and Galak (2012) showed many of the social interactions that occur between individuals and institutions via SMP and showed that SMP can have an impact on marketing results such as improving sales, brand loyalty, and acquiring new customers. Gordon et al. (2019) referred to the added value of advertising on SMP and how it affects the spread of new products. Godes and Mayzlin (2004) showed that SMP are cost-effective and one of the efficient options for accessing and collecting information from consumers, as well as their ability to influence their behavior. Abzari (2014) explores the impact of SMP on sales. It was found that SMP have important impacts on the banks's marketing performance and that it is an appropriate way to influence CB.

Marketing activities via SMP also affect $\mathrm{CB}$, as after consumer exposure to marketing activities and advertisements across platforms, they begin to observe a specific product in a different direction (Kitani, 2017). In this context, Lantos (2015) assumes that some ads are so important that they give the consumer planned enough to search for the promoted item. According to research by Ducey and Samu (2015), 60\% of people can remember an ad they have previously seen, and this indicates that there is a way of advertising on SMP that attracts consumers and thus affects their behavior.

\subsection{Innovation Marketing (IM)}

In order to comprehend innovation in the field of marketing, the study will discuss, first and foremost, the concept of innovation, which has acquired different meanings in various business areas (Hunt \& Morgan, 1995). Gupta \& Malhotra (2013) saw that innovation pioneer Schumpeter had defined innovation in 1934 as "a unique way of making things, or a different combination of parts of production". However, innovation in the most general knowledge is the practical utilization of unique ideas (Millson \& Wilemon, 2007). With this comprehensive meaning, it is required to distinguish between the concepts of creativity and innovation, where creativity leads with the ability to generate unique ideas, while innovation refers to the activity that describes the process of achieving unique ideas and creating unique things (Tokognon et al., 2015).

IM is an all-inclusive concept as it means innovation in all fields of marketing activity, and therefore it is not tied to a specific field of marketing, such as innovation in the field of product or in the field of advertising only, but rather includes all other marketing aspects, as IM involves all actions linked with directing the product from the bank to the last consumer (Olughor, 2015). IM strives to provide consumers better than competitors via skill in defining and fitting their needs and wishes accurately, and matching them with the capabilities of the bank, and if the primary goal of marketing is to meet the current needs of consumers in a manner consistent with the capabilities and goals of the bank, then IM seeks to achieve discovering the underlying needs of consumers and meeting them, as the current needs are those that are present in the minds of consumers, where they can easily express them, and through traditional market research methods, these needs can be identified, as for latent needs, they mean those needs that consumers today are not aware of. So, they are either unable to express it, or unwilling to express it (Atalay, 2013).

Besides, IM can discover the latent needs of consumers and meet them in order to have a leadership in the market, and we find that the category of innovative products and banking services is completely related to the underlying needs, which innovative marketing has a large role in defining, Thus, IM may create a competitive advantage for the bank, and it is intended that the product or service provided by the bank enjoys an unparalleled advantage over competitors' products (Zraqat, 2019) that is, the product or the banking service has an advantage that is unique to others, in other words, the source of this feature lies in the fact that the product is highly compatible with the needs of consumers in comparison with the products of competitors, by precisely identifying the current needs of consumers and the latent that marketing innovation had a major role in discovering (Lendel \& Varmus, 2014). The definition of IM has taken a modern model because global business trends have partially transformed the flow of innovative ideas from producer to consumer. Where IM includes the implementation of new marketing methods that involve major changes in the design, promotion and pricing of banking products and services (Onwumere \& OziomaEleodinmuo 2015). Innovative marketing also includes major changes in the way services and products are presented, improvement of new media, new pricing and sales strategies (Tetterh \& Essegbey, 2014), where marketing innovation leads to a whole host of adjustments in the bank's marketing activities (Moreira et al., 2012).

Seng and Ping (2016) concluded that product innovation is an important factor in creating motives for consumers and influencing their buying intent, as the innovative factors for the product can change the consumer's attitude towards the innovative product, thus creating the intention to buy. Joueid and Coenders (2018) pointed out that innovation in the marketing mix is the main driver of sales for the banks's new products, as marketing innovation in all its 
dimensions affects consumers' learning and increases their purchasing motivation. Aksoy (2017) showed that a culture of innovation is an effective source for both marketing innovation and product innovation, in addition to that a culture of innovation is a precondition for achieving organizational, marketing, and managerial success. Monteiro and Giuliani (2017) concluded that companies 'adoption of technology concepts in the production and marketing of their products affects consumers' attitudes and purchasing decisions and that innovation, participation, and experience with the Internet influence the consumer's buying decision in the digital environment.

\subsection{Study Hypotheses}

Based on the literature review above, the following hypotheses were formulated:

H01: There is effect of MSMP during the COVID-19 pandemic on CB in Jordanian banks.

H02: There is no effect of MSMP during the COVID-19 pandemic on IM in Jordanian banks.

H03: There is no effect of IM during the COVID-19 pandemic on CB in Jordanian banks.

H04: There is no effect of MSMP during the COVID-19 pandemic on CB through IM in Jordanian banks.

\section{Study Methodology}

\subsection{Population and Sample}

The study population is represented by the (16) Jordanian banks. An intended random sample consisting of 1,250 clients of the age group between 20 to 40 years was chosen. 1250 questionnaires were distributed via WhatsApp, and the process of distributing and retrieving the questionnaires was done electronically due to the COVID-19 pandemic and the ban imposed in Jordan. Of these, 856 questionnaires were valid for statistical analysis, after excluding 116 questionnaires for lack of completion, and thus the percentage of recovered and valid for statistical analysis is $68.48 \%$ of the total distributed questionnaires.

\subsection{Reliability Tests}

To test the reliability of study tool, Cronbach's Alpha was used and the results revealed a Cronbach's alpha coefficient was $(0.817)$ for all items, and values of $(\alpha)$ range from 0.725 to 0.790 , which refers the questionnaire is reliable. The values of $(\alpha)$ of the study variables of the study were as in Table 1:

Table 1. Reliability tests of model variables

\begin{tabular}{ll}
\hline Variable & Reliability Coefficient $(\boldsymbol{\alpha})$ \\
\hline MSMP & 0.771 \\
\hline CB & 0.790 \\
\hline IM & 0.725 \\
\hline All Paragraphs & $\mathbf{0 . 8 1 7}$
\end{tabular}

Source: Develop by the researcher

\subsection{Descriptive Analysis}

The mean, standard deviation (SD), minimum, maximum and correlations among variables are represented in Table 2.

Table 2. Descriptive statistics and correlation coefficient

\begin{tabular}{llllllll}
\hline & Mean & SD & Min & Max & Correlation & \\
\hline & & & & & MSMP & CB & IM \\
\hline MSMP & 3.299 & 0.909 & 1.000 & 5.000 & 1.000 & & \\
\hline CB & 3.509 & 0.821 & 1.000 & 5.000 & $0.893^{* *}$ & 1.000 & \\
\hline IM & 3.208 & 0.904 & 1.000 & 5.000 & $0.848^{* *}$ & $0.780^{* *}$ & 1.000 \\
\hline
\end{tabular}

** Correlation is significant at the 0.01 level (2-tailed). 
The descriptive measures indicated that (CB) was with highest mean (3.509), while (MSMP) was with mean (3.299). Moreover, the lowest mean was for (IM), (3.208). The correlation coefficient values indicated that there was a significant relationship among model variables.

The results of the descriptive statistics related to MSMP indicate the interest of banks in communicating with their target customers, creating awareness of the brand, and selling their products or services during the COVID-19 pandemic, as banks draw consumers' attention with good content that interests them, as evidenced by the interest in interactive content that encourages customers to interact with marketers' pages, by providing some advice or helping consumers in different areas and behind brand loyalty. This increases the chances of publishing the advertisement presented to the target group.

With regard to $\mathrm{CB}$, the results indicate the banks' interest in learning about CB during the COVID-19 pandemic, and the researcher attributes this result to that Jordanian banks are constantly keen to meet the various needs of consumers, with their interest in constantly providing information about the prices of their products and services via SMP to create motivation at consumers and this is because the bank realizes the importance of satisfying consumers to maintain their motivation towards the services it provides. In addition, banks are keen to transparently disclose all information related to their services, due to their awareness of the importance of building a positive mental image of their services, due to the effective role that this plays in developing consumer awareness about the products and services they provide, as the consumer depends to some extent on his previous experiences in choosing the bank's services, taking into account the banks' demographic characteristics of the consumer when providing their services. The banks also obtain a positive evaluation of the services provided to the consumer through the evaluation options on SMP, as well as the banks seeking to document consumer trends and tendencies and follow them periodically and continuously. It is also interested in offering its products and services more easily to all categories of consumers, in addition to its endeavor to consolidate its services in the consumer's memory, and work to motivate the consumer to see advertisements for its products and services.

With regard to IM, the results indicate that banks attach great importance to achieving consumer satisfaction. In order to maintain good relations with them, for this purpose, these banks provide the necessary resources to develop new services, and seek to study the needs of the surrounding environment in terms of new services; This is in order to provide a variety of innovative products and services, by using modern technology in designing new services whose services are of high quality. It is imperative to conduct a continuous survey of the services provided by competitors in order to compare their products with those of competitors, as well as study the competitive environment; In order to keep pace with its continuous development. In addition, banks attach appropriate importance to innovation in pricing strategy during the COVID-19 pandemic and their use of advanced methods and mechanisms in pricing their services, as well as their commitment to the regulations and instructions followed in pricing strategies, as well as the bank's management having flexibility within the followed regulations and instructions related to pricing strategies. Provide many facilities in electronic payment methods for consumers.

\subsection{Confirmatory Factor Analysis}

The results of confirmatory factor analysis (CFA) are shown in Table (3)

Table 3. CFA results

\begin{tabular}{llllll}
\hline Measure & CMIN/DF & CFI & GFI & NFI & RMSEA \\
\hline Threshold value & $<5$ & $>0.90$ & $>0.90$ & $>0.90$ & $<0.10$ \\
\hline Result & 4.414 & 0.971 & 0.959 & 0.965 & 0.073 \\
\hline
\end{tabular}

The above table showed that CFA measures represent a good fit as CFI $=0.971$, GFI $=0.959$, NFI $=0.965$, and RMSEA $=0.073$ are all within acceptable range, that refers to model fit. 


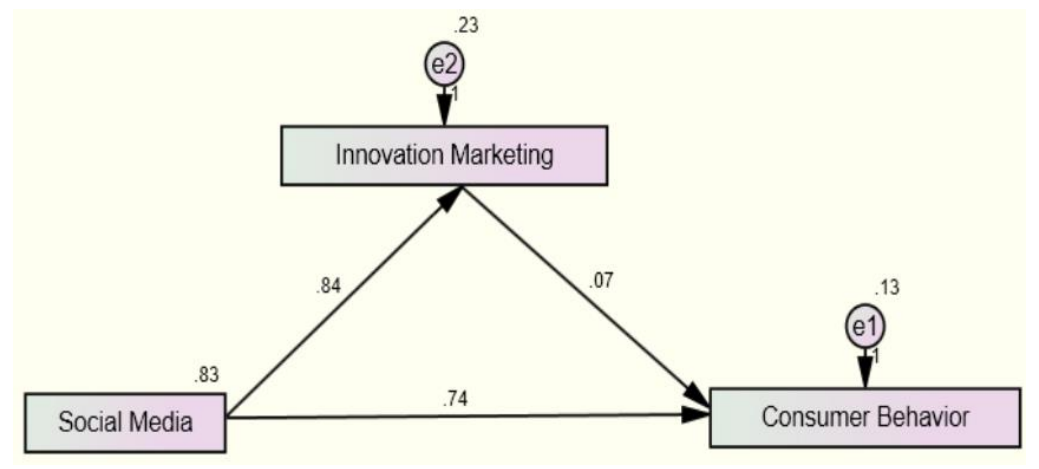

Figure 1. The results estimated through AMOS

\section{Results and Discussion}

Table 4. Regression analysis results

\begin{tabular}{lllll}
\hline & Estimate $(\beta)$ & S.E. & C.R. & p-value \\
\hline $\mathbf{M S M P ~} \rightarrow \mathbf{I M}$ & 0.843 & 0.018 & 46.851 & 0.000 \\
\hline $\mathbf{I M ~} \rightarrow \mathbf{C B}$ & 0.073 & 0.026 & 2.783 & 0.005 \\
\hline $\mathbf{M S M P ~} \rightarrow \mathbf{C B}$ & 0.745 & 0.026 & 28.538 & 0.000 \\
\hline
\end{tabular}

Regression results indicated that the effect of (MSMP) on (IM) was significant ( $\beta=0.843, p=0.000$ ), so there is a significant relation between independent and mediator variable. This result indicates the importance of MSMP during the COVID-19 pandemic in promoting innovative marketing, and this result is consistent with what Smith (2012) pointed out that SMP help companies communicate with their target customers in an innovative way, enabling them to create brand awareness and sale of its products or services (Smith, 2012). The result also shows that MSMP helps innovate in the way social interactions occur between individuals and institutions (Stephen \& Galak, 2012; Gordon et al., 2019).

Also, the effect of (IM) on (CB) was significant $(\beta=0.073, p=0.005)$, which means there is relation between mediator and dependent variable. This means that Jordanian banks follow practices that enable them to promote IM, as these banks seek to provide the necessary resources to develop new services, study the needs of the surrounding environment for new services, in addition to providing a variety of new services, as well as seeking to use modern technology in design new services, so that their services are of high quality, and banks have specialized human competencies that use advanced methods and mechanisms in IM and distinguish the IM strategies of banks with flexibility. This result is consistent with the findings of the study (Seng \& Ng, 2016). This indicated that the innovative factors of the product can change the consumer's attitude towards the innovative product, thus creating the intention to buy. This result is also consistent with the findings of the study (Aksoy, 2017). Which indicated that product innovation strategy positively affects brand loyalty? This result is also consistent with the findings of the study (Joueid \& Coenders, 2018). Which showed that innovation in the marketing mix is the main driver of sales of the new products, as IM in all its dimensions affects consumers' learning and increases their purchasing motivation. Thus, it increases the market share of the bank and improves its overall performance. The result is also consistent with what Zwanka and Buff (2021) indicated, which indicated that the COVID-19 pandemic will lead to shifts in CB around the world, which will necessitate marketers to find new innovations in marketing strategies to match new patterns of CB. This result is also consistent with the results of Akter and Sultana's (2020) study, which showed innovation in digital marketing communications, had an impact on $\mathrm{CB}$ at all stages of purchasing decisions, and that customers had positive feelings about MSMP during the COVID-19 pandemic.

Moreover, the effect of (MSMP) on (CB) was significant $(\beta=0.745, p=0.000)$, which indicates there is a significant effect of independent variable on dependent without a mediation effect. This result indicates the importance of MSMP in influencing CB during the COVID-19 pandemic in Jordanian banks. Therefore, banks must keep abreast of market psychology during the pandemic to learn how it affects the way consumers behave. The pandemic has led 
to important changes in $\mathrm{CB}$ around the world. Consumers are becoming more rational, interested in SMP, and enjoying skills and multitasking capabilities in the virtual world, as consumers during the COVID-19 pandemic individually evaluate when making purchasing decisions by searching the internet (Clemens et al., 2020). This finding is consistent with that of Coibion et al. (2020) study, which showed that consumers are reducing their expenditures related to luxuries and luxury products while increasing expenditures on emergency products and household supplies and that this is done through online shopping in all stages of purchasing decision behavior during the COVID-19 pandemic.

Table 5. Direct, indirect and total effect model of mediation analysis

\begin{tabular}{|c|c|c|c|c|c|c|}
\hline & \multicolumn{2}{|c|}{ Direct Effect } & \multicolumn{2}{|c|}{ Indirect Effect } & \multicolumn{2}{|c|}{ Total Effect } \\
\hline & MSMP & IM & MSMP & IM & MSMP & IM \\
\hline IM & $\begin{array}{l}0.843 \\
(0.010)\end{array}$ & 0.000 & 0.000 & 0.000 & $\begin{array}{l}0.843 \\
(0.010)\end{array}$ & 0.000 \\
\hline CB & $\begin{array}{l}0.745 \\
(0.010)\end{array}$ & $\begin{array}{l}0.073 \\
(0.039)\end{array}$ & $\begin{array}{l}0.062 \\
(0.039)\end{array}$ & 0.000 & $\begin{array}{l}0.806 \\
(0.010)\end{array}$ & $\begin{array}{l}0.073 \\
(0.039)\end{array}$ \\
\hline
\end{tabular}

The results of above table showed that (IM) partially mediated the relation between (MSMP) and (CB). The mediation effect is significant as indirect effect $(\beta=0.062, \mathrm{p}=0.039)$ of (MSMP) on (CB) is due to the mediator. Therefore, in the total effect ( $\beta=0.806, p=0.010)$ of (S MSMP) on (CB). This result indicates that IM touches all activities associated with directing the product from the bank to the final consumer (Olughor, 2015). Where IM works when using SMP to satisfy consumers through ingenuity in identifying and meeting their needs and desires accurately, and matching them with the capabilities of the bank, as IM during the COVID-19 pandemic helps banks in discover and meet the changes in the latent needs of consumers. Through innovation in MSMP can research the market to identify these needs, and understand consumer trends and tendencies (Atalay, 2013). Besides, IM can discover the underlying needs of consumers and meet them. The innovation in the use of MSMP lies in the fact that the products and services provided by banks will suit the needs of consumers, by accurately identifying the current needs of consumers and the latent that IM had a major role in discovering (Lendel \& Varmus, 2014). This finding indicates that IM in times of the COVID-19 pandemic offers a new paradigm. Because global business trends have partially shifted the flow of innovative ideas from the producer to the consumer, where IM involves implementing new marketing methods that involve major changes in product design, product promotion and pricing (Onwumere \& OziomaEleodinmuo 2015), where IM leads to a whole range of adjustments in the bank's marketing activities (Moreira et al., 2012).

\section{Conclusion}

This study aimed to identify the impact of MSMP during the COVID-19pandemic on CB in Jordanian banks. In addition to knowing the role of IM in improving the ability of the impact of MSMP during the COVID-19 pandemic on $\mathrm{CB}$, the study population consisted of all Jordanian banks. The process of distributing and retrieving the questionnaires was carried out electronically due to the COVID-19 pandemic and the ban imposed in Jordan.

The study found that banks are interested in communicating with their customers via SMP, creating awareness of the brand, and selling their products or services during the COVID-19 pandemic, as banks draw consumers' attention with good content that interests them, as evidenced by the interest in interactive content that encourages customers to interact with pages marketers, by providing some advice or helping consumers in different areas and behind brand loyalty. This increases the chances of publishing the advertisement presented to the target group. The study also found the Jordanian banks interest in learning about CB during the COVID-19 pandemic. The researcher attributes this result to the fact that Jordanian banks are constantly keen to meet the various needs of the consumer, with their interest in constantly providing information about the prices of their products and services via SMP to create motivation among consumers. Because the Jordanian banks realizes the importance of satisfying consumers to maintain their motivation towards the services it provides. With regard to IM, the results indicate that Jordanian banks attach great importance to achieving consumer satisfaction. In order to maintain good relations with them, for this purpose, these banks provide the necessary resources to develop new services, and seek to study the needs of the surrounding environment in terms of new services; This is in order to provide a variety of innovative products and 
services, by using modern technology to design new services whose services are of high quality. Also, Jordanian banks are attaching appropriate importance to IM strategy during the COVID-19 pandemic and using advanced methods and mechanisms in providing their services.

The study found an impact of MSMP during the COVID-19 pandemic in promoting IM, as SMP contribute to banks communicating with their target customers in an innovative way, enabling them to create brand awareness and sell their products or services. Also, MSMP helps to innovate in the way social interactions occur between individuals and institutions. The study also found an impact of MSMP in influencing CB during the COVID-19 pandemic, and accordingly, Jordanian banks must keep pace with market psychology during the pandemic to learn how it affects the way consumers behave. The pandemic has led to important changes in CB around the world. Consumers are becoming more rational, interested in SMP, and enjoying skills and multitasking capabilities in the virtual world, as consumers during the COVID-19 pandemic individually evaluate when making purchasing decisions by searching the internet. The results of the study also showed that there is an impact of IM in improving the impact of MSMP on CB. Where IM works when using SMP to satisfy consumers through the ingenuity in identifying and meeting their needs and desires accurately, and matching them with the capabilities of the bank, as IM during the COVID-19 pandemic helps to discover and meet the changes in the latent needs of consumers.

The study recommends the need to pay attention to MSMP as it adds two very important elements to traditional marketing during the COVID-19 pandemic. First, it introduces new marketing channels that are completely connected via the internet and thus is immune to the consequences of social distancing of COVID-19. Second, customers leave an impact as a result of their use of SMP in the form of digital data that allows each marketing campaign to be stored, tracked, and monetized through its channels. Jordanian banks can also benefit from the cost advantage, as MSMP is considered one of the least expensive methods of marketing. In addition, it allows direct dialogue between the customer and the bank, so the bank knows customer problems and contacts them to solve them, or know their requirements, as consumers tend to prefer the internet over personal interaction, such as calling the phone or going to the store.

\section{References}

Abzari, M., Ghassemi, R. A., \& Vosta, L. N. (2014). Analysing the effect of social media on brand attitude and purchase intention: The case of Iran Khodro Company. Procedia-Social and Behavioral Sciences, 143, 822-826. https://doi.org/10.1016/j.sbspro.2014.07.483

Aksoy, H. (2017). How do innovation culture, marketing innovation and product innovation affect the market performance of small and medium-sized enterprises (SMEs). Technology in Society, 51(4), 133-141. https://doi.org/10.1016/j.techsoc.2017.08.005

Akter, M., \& Sultana, N. (2020). Digital marketing communication and consumer buying decision process in pandemic standpoint (COVID-19): An empirical study of Bangladeshi customers' in branded cosmetics perspective. Open Journal of Business and Management, 8, 2696-2715. https://doi.org/10.4236/ojbm.2020.86167

Algharabat, R., Rana, N. P., Alalwan, A. A., Baabdullah, A., \& Gupta, A. (2020). Investigating the antecedents of customer brand engagement and consumer-based brand equity in social media. Journal of Retailing and Consumer Services, 53. https://doi.org/10.1016/j. jretconser.2019.01.016

Alotaibi, M. Z., Alotibi, M. F., \& Zraqat, O. M. (2021). The impact of information technology governance in reducing cloud accounting information systems risks in telecommunications companies in the State of Kuwait. Modern Applied Science, 15(1). https://doi.org/10.5539/mas.v15n1p143

Appel, G., Grewal, L., Hadi, R., \& Stephen, A. T. (2020). The future of social media in marketing. Journal of the Academy of Marketing Science, 48(1), 79-95. https://doi.org/10.1007/s11747-019-00695-1

Arafat, S. Y., Kar, S. K., Marthoenis, M., Sharma, P., Apu, E. H., \& Kabir, R. (2020). Psychological underpinning of panic buying during pandemic (COVID-19). Psychiatry Research, 289, 113061. https://doi.org/10.1016/j.psychres.2020.113061

Atalay, M., Anafarta, N., \& Sarvan, F. (2013). The relationship between innovation and firm performance: An empirical evidence from Turkish automotive supplier industry. Procedia-social and Behavioral Sciences, 75, 226-235. https://doi.org/10.1016/j.sbspro.2013.04.026

Belch, G. E., \& Belch, M. A. (2004). Advertising and promotion: An integrated marketing communications perspective (6th ed.). New York: NY: McGraw-Hill. 
Brizi, A., \& Biraglia, A. (2021). "Do I have enough food?" How need for cognitive closure and gender impact stockpiling and food waste during the COVID-19 pandemic: A cross-national study in India and the United States of America. Personality and Individual Differences, 168, 110396. https://doi.org/10.1016/j.paid.2020.110396

Chen, S., \& Lin, C. (2019). Understanding the effect of social media marketing activities: the mediation of social identification, perceived value, and satisfaction. Technological Forecasting and Social Change, 140, 22-32. https://doi.org/10.1016/j.techfore.2018.11.025

Clemens, K., Matkovic, J., Faasse, K., \& Geers, A. (2020). Determinants of safety-focused product purchasing in the United States at the beginning of the global COVID-19 pandemic. Safety Science, 130, 104894. https://doi.org/10.1016/j.ssci.2020.104894

Coibion, O., Gorodnichenko, Y., \& Weber, M. (2020). The cost of the COVID-19 crisis: lockdowns, macroeconomic expectations, and consumer spending. National Bureau of Economic Research, Working Paper, No. w27141. https://doi.org/10.3386/w27141

Dahiya, R. (2013). Consumers' attitude towards digital marketing. Review of Professional Management- A Journal of New Delhi Institute of Management, 11(2), 42-51. https://doi.org/10.20968/rpm/2013/v11/i2/88697

Dammeyer, J. (2020). An explorative study of the individual differences associated with consumer stockpiling during the early stages of the 2020 Coronavirus outbreak in Europe. Personality and Individual Differences, 167, 110263. https://doi.org/10.1016/j.paid.2020.110263

Ducey, N., \& Samu, S. (2015). The impact of advertising on the success of brand and line extensions. In M. Moore, \& R. Moore (Eds.), New Meanings for Marketing in a New Millennium. Springer, Cham. https://doi.org/10.1007/978-3-319-11927-4_30

Dumitriu, D., \& Popescu, M. A. M. (2020). Artificial intelligence solutions for digital marketing. Procedia Manufacturing, 46, 630-636. https://doi.org/10.1016/j.promfg.2020.03.090

Fernando, I., Perera, J., Udawaththa, I., Rathnayake, C., \& Madushani, M. (2021). Consumer stockpiling behaviour within the face of COVID-19 pandemic: systematic review. https://doi.org/10.2139/ssrn.3770202

Godes, D., \& Mayzlin, D. (2004). Using online conversations to study word-of-mouth communication. Marketing Science, 23(4), 545-560. https://doi.org/10.1287/mksc.1040.0071

Gordon, B. R., Zettelmeyer, F., Bhargava, N., \& Chapsky, D. (2019). A comparison of approaches to advertising measurement: Evidence from big field experiments at Facebook. Marketing Science, 38(2), 193-225. https://doi.org/10.1287/mksc.2018.1135

Gupta, S., \& Malhotra, N. (2013). Marketing innovation: a resource-based view of international and local firms. Marketing Intelligence \& Planning, 31(2), 111-126. https://doi.org/10.1108/02634501311312026

Harahsheh, A., Alharafsheh, M., Zraqat, O. M., Houssien, A. H. M. A., \& Shajrawi, A. (2021). Crisis management strategies during the COVID-19 pandemic and its impact on performance developing of Jordanian Universities: The mediating role of strategic ambidexterity. PalArch's Journal of Archaeology of Egypt/Egyptology, 18(4), 3985-4007.

Hunt, S. D., \& Morgan, R. M. (1995). The comparative advantage theory of competition. Journal of Marketing, 59(2), 1-15. https://doi.org/10.1177/002224299505900201

Jermsittiparsert, K., \& Chankoson, T. (2019). Behavior of tourism industry under the situation of environmental threats and carbon emission: Time series analysis from Thailand. International Journal of Energy Economics and Policy, 9(6), 366-372. https://doi.org/10.32479/ijeep.8365

Joueid, A., \& Coenders, G. (2018). Marketing innovation and new product portfolios. A compositional approach. Journal of Open Innovation: Technology, Market, and Complexity, 4(2), 19. https://doi.org/10.3390/joitmc4020019

Kitani, N. (2016). The development and independency of the media in Republic of Albania (1990-2015). Student's Social Science Journal, 1(1), 169-176.

Kujur, F., \& Singh, S. (2017). Engaging customers through online participation in social networking sites. Asia Pacific Management Review, 22(1), 16-24. https://doi.org/10.1016/j.apmrv.2016.10.006

Lantos, G. P. (2015). Consumer behaviour in action: Real-life applications for marketing managers. Routledge, Taylor \& Francis eBooks.

Lendel, V., \& Varmus, M. (2014). Evaluation of the innovative business performance. Procedia-Social and Behavioral Sciences, 129, 504-511. https://doi.org/10.1016/j.sbspro.2014.03.707 
Manzoor, U., Baig, S. A., Hashim, M., \& Sami, A. (2020). Impact of social media marketing on consumer's purchase intentions: the mediating role of customer trust. International Journal of Entrepreneurial Research, 3(2), 41-48. https://doi.org/10.31580/ijer.v3i2.1386

Maulana, N. (2020). Research trends in marketing science before COVID-19 outbreak: a literature review. Management \& Marketing. Challenges for the Knowledge Society, 15(s1), 514-533. https://doi.org/10.2478/mmcks-2020-0030

Millson, M., \& Wilemon, D. (2007). The strategy of managing innovation and technology. Pearson. Retrieved from https://digitalcommons.csumb.edu/fac_books/38

Monteiro, T. A., \& Giuliani, C. G. (2017). Consumer's attitude, innovation, involvement and experience in digital world. European Journal of Scientific Research, 147(4), 389-402.

Moreira, J., Silva, M. J., Simões, J., \& Sousa, G. (2012). Drivers of marketing innovation in Portuguese firms. Amfiteatru Economic Journal, 14(31), 195-206. Retrieved from http://hdl.handle.net/10419/168752

Mowen, J. C. (1987). Consumer behavior. New York, Macmillan Publishing Company.

Murphy, M. C., \& Dweck, C. S. (2016). Mindsets shape consumer behavior. Journal of Consumer Psychology, 26(1), 127-136. https://doi.org/10.1016/j.jcps.2015.06.005

Olughor, R. J. (2015). Effect of innovation on the performance of SMEs organizations in Nigeria. Management, 5(3), 90-95. https://doi.org/10.5923/j.mm.20150503.02

Onwumere, J., \& Ozioma-Eleodinmuo, P. (2015). Enhancing innovativeness among small and medium scale (SMEs) leather enterprises to boost performance in Abia State, Nigeria. International Journal of Community and Cooperative Studies, 3(1), 1-4.

Seng, L. C., \& Ping, N. S. (2016). The influence of product innovation toward consumer purchase intention. International Journal of Economics, Commerce and Management, 4(4), 773-782.

Smith, K. T. (2012). Longitudinal study of digital marketing strategies targeting millennials. Journal of Consumer Marketing, 29, 86-92. https://doi.org/10.1108/07363761211206339

Stephen, A. T., \& Galak, J. (2012). The effects of traditional and social earned media on sales: A study of a microlending marketplace. Journal of Marketing Research, 49(5), 624-639. https://doi.org/10.1509/jmr.09.0401

Tetteh, E. K., \& Essegbey, G. O. (2014). Firm level innovation: The case of Ghanaian firms. European Journal of Business and Innovation Research, 2(2), 1-18.

Theep, K. M. I. A. (2021). Digital marketing during COVID-19: a Jordanian viewpoint. PalArch's Journal of Archaeology of Egypt/Egyptology, 18(4), 167-197. Retrieved from https://archives.palarch.nl/index.php/jae/article/view/5603

Tokognon, R., Ackah, O., \& Yunfei, S. (2015). Building sustainable small and micro enterprises in Benin: Is innovation policy the way forward. International Journal of Economics, Commerce and Management, 3(6), 654-663.

Walters, J. (1974). Organizational Behavior - Human Behavior at work (9th ed.). New Delhi: Tata McGraw Hill.

Zraqat, O. M. (2019). Sustainability practices disclosure and value relevance: evidence from Jordan. Modern Applied Science, 13(9), 75-86. https://doi.org/10.5539/mas.v13n9p75

Zraqat, O. M. (2020). The moderating role of business intelligence in the impact of big data on financial reports quality in Jordanian telecom companies. Modern Applied Science, 14(2), 71-85. https://doi.org/10.5539/mas.v14n2p71

Zwanka, R. J., \& Buff, C. (2021). COVID-19 generation: a conceptual framework of the consumer behavioral shifts to Be caused by the COVID-19 pandemic. Journal of International Consumer Marketing, 33(1), 58-67. https://doi.org/10.1080/08961530.2020.1771646

\section{Copyrights}

Copyright for this article is retained by the author(s), with first publication rights granted to the journal.

This is an open-access article distributed under the terms and conditions of the Creative Commons Attribution license (http://creativecommons.org/licenses/by/4.0/). 